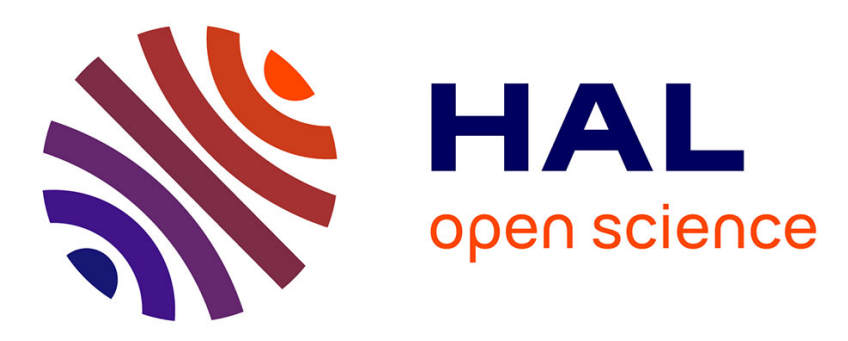

\title{
Two new biologically active triterpenoidal saponins acylated with salicylic acid from Albizia adianthifolia
}

Mohamed Haddad, Tomofumi Miyamoto, Véronique Laurens, Marie-Aleth Lacaille-Dubois

\section{- To cite this version:}

Mohamed Haddad, Tomofumi Miyamoto, Véronique Laurens, Marie-Aleth Lacaille-Dubois. Two new biologically active triterpenoidal saponins acylated with salicylic acid from Albizia adianthifolia. Journal of Natural Products, 2003, 66, pp.372-377. 10.1021/np020391q · ird-01382646

\section{HAL Id: ird-01382646 \\ https://hal.ird.fr/ird-01382646}

Submitted on 17 Oct 2016

HAL is a multi-disciplinary open access archive for the deposit and dissemination of scientific research documents, whether they are published or not. The documents may come from teaching and research institutions in France or abroad, or from public or private research centers.
L'archive ouverte pluridisciplinaire HAL, est destinée au dépôt et à la diffusion de documents scientifiques de niveau recherche, publiés ou non, émanant des établissements d'enseignement et de recherche français ou étrangers, des laboratoires publics ou privés. 


\title{
Two New Biologically Active Triterpenoidal Saponins Acylated with Salicylic Acid from Albizia adianthifolia
}

\author{
Mohamed Haddad, ${ }^{\dagger}$ Tomofumi Miyamoto, ${ }^{\ddagger}$ Véronique Laurens, ${ }^{\S}$ and Marie-Aleth Lacaille-Dubois*,† \\ Laboratoire de Pharmacognosie, Unité MIB J E 2244, Faculté de Pharmacie, Université de Bourgogne, 7, Bd. J eanne d'Arc, \\ BP 87900, 21079 Dijon Cedex, France, Graduate School of Pharmaceutical Sciences, Kyushu University, Fukuoka, J apan, and \\ Groupe I mmunol ogie Comparée, UMR CNRS 5548, Faculté des Sciences, Université de Bourgogne, 6, Bd. Gabriel, \\ 21079 Dijon Cedex, France
}

Received August 30, 2002

\begin{abstract}
Two new oleanane-type triterpene saponins, adianthifoliosides A (1) and B (2), were isolated from a 95\% ethanolic extract of roots of Albizia adianthifolia. Their structures were elucidated mainly by using a combination of $600 \mathrm{MHZ}$ ID and 2D NMR techniques (COSY, NOE SY, TOCSY, HSQC, and HMBC) and by FABMS and HRESIMS. Compounds $\mathbf{1}$ and $\mathbf{2}$ were characterized as glycosides of acacic acid acylated by an o-hydroxybenzoyl unit. The crude saponin mixture (CSM), compounds $\mathbf{1}$ and $\mathbf{2}$ together with $\mathbf{3}$ and 4 (prosapogenins obtained from the mild alkaline hydrolysate of the CSM), were evaluated for immunomodulatory activity on the J urkat $T$ cell line and for hemolytic property against sheep erythrocytes. Compound $\mathbf{2}$ and, to a lesser extent, $\mathbf{1}$ and $\mathbf{3}$ were found to exhibit a dose-dependent immunomodulatory effect in the concentration range $10^{-2}-10 \mu \mathrm{M}$, whereas 4 showed a lymphoproliferative activity in the same concentration range. Among the compounds tested, only $\mathbf{1}$ and $\mathbf{2}$ were found to be hemolytic.
\end{abstract}

The genus Albizia comprises about 150 species widely distributed in the tropics, with the greatest diversity in Africa and Central and South America. ${ }^{1}$ Albizia species have been reported to contain alkaloids, steroids, triterpenoid saponins, and flavonols. ${ }^{2}$ Some saponins such as julibrosides $\mathrm{J}_{1}, \mathrm{~J}_{2}$, and J 9 from Al bizia julibrissin ${ }^{3,4}$ possess various biological effects, such as inhibitory activity against the KB cancer cell line in vitro.

In a previous contribution, we reported the isolation and structure determination of two prosapogenins ( $\mathbf{3}$ and $\mathbf{4}$ ) isolated from the butanol extract of the mild alkaline hydrolysate of the crude saponin fraction of the roots of Albizia adianthifolia (Schumach.) W. F. Wight (Mimosaceae). ${ }^{5}$ The further investigation of the saponins of this plant, obtained as a complex mixture, afforded two new acylated triterpene saponins, adianthifoliosides $A(\mathbf{1})$ and $B$ (2), from the $95 \%$ ethanolic extract of the roots of $A$. adianthifolia. This paper deals with the isolation and structure elucidation of these new acylated triterpene glycosides ( $\mathbf{1}$ and $\mathbf{2}$ ) and the evaluation of the immunomodulatory activity of 1-4 (Chart 1) and the crude saponin mixture (CSM) on J urkat T cell proliferation (human T cell leukemia) and the hemolytic activity of $\mathbf{1 - 4}$ on sheep erythrocytes.

\section{Results and Discussion}

The $95 \%$ ethanolic extract of the roots of A. adianthifolia was purified by precipitation with diethyl ether, yielding a crude saponin mixture, which was then dialyzed for 2 days. The powder obtained was submitted to column chromatography over Sephadex LH-20 and was separated by repeated medium-pressure liquid chromatography (MPLC) over normal Si gel, yielding compounds $\mathbf{1}$ and $\mathbf{2}$. Their structures were elucidated mainly by 1D and 2D NMR spectroscopy (COSY, TOCSY, NOESY, HSQC, and $\mathrm{HMBC}$ ) and by FABMS and HRESIMS.

* To whom correspondence should be addressed. Tel: 0033-3-80393229. Fax: 0033-3-80393300. E-mail: malacd@u-bourgogne.fr.

† Université de Bourgogne, J E 2244.

‡ Kyushu University.

§ Université de Bourgogne, UMR CNRS 5548.
Compound $\mathbf{1}$ was obtained as an amorphous powder. The HRESI mass spectrum (positive-ion mode) exhibited a quasimolecular ion peak at m/z 1714.7490 [M + Na] ${ }^{+}$(calcd 1714.7465), consistent with a molecular formula of $\mathrm{C}_{79} \mathrm{H}_{121^{-}}$ $\mathrm{NO}_{38}$. Upon acid hydrolysis with $2 \mathrm{~N}$ TFA at $120{ }^{\circ} \mathrm{C}, \mathbf{1}$ afforded the aglycon $\mathbf{6}$, which was identified as acacic acid lactone (the 21,28-lactone derivative of acacic acid obtained under the experimental conditions used), by comparison of its NMR data with literature values. ${ }^{6}$ The native aglycon was characterized as acacic acid from the 2D NMR spectra from 1. The sugars obtained from the saponin hydrolysate were identified as glucose, fucose, rhamnose, arabinose, and xylose by comparison with authentic samples. However, the presence of an N-acetamido group [IR 1639 and $1570 \mathrm{~cm}^{-1}$; ${ }^{1} \mathrm{H}$ NMR $\delta_{\mathrm{H}} 2.13(3 \mathrm{H}, \mathrm{s}, \mathrm{MeCO})$ and $\delta_{\mathrm{H}} 8.91$ $(1 \mathrm{H}, \mathrm{d}, \mathrm{J}=8.8 \mathrm{~Hz}, \mathrm{NH}) ;{ }^{3} \mathrm{C} \mathrm{NMR} \delta_{\mathrm{C}} 22.9$ and 171.9], together with the ${ }^{1} \mathrm{H}$ and ${ }^{13} \mathrm{C}$ NMR data of the $\mathrm{C}-2$ of the $\mathrm{GlC}_{1}\left(\delta_{\mathrm{H}} 4.40\right.$ and $\left.\delta_{\mathrm{C}} 56.8\right)$, suggested the presence of one 2-(acetylamino)-2-deoxyglucose (GIC NAc) unit. In addition, alkaline hydrolysis of $\mathbf{1}$ afforded salicylic acid (SA, ohydroxybenzoic acid, 7), identified by comparison of its ${ }^{1} \mathrm{H}$ and ${ }^{13} \mathrm{C}$ NMR data with those reported, ${ }^{7}$ and a prosapogenin whose spectroscopic N M R data were in good agreement with those of 4. ${ }^{5}$ The above data suggested that 1 is a 21acyl-3,28-bisdesmoside. This was confirmed by the observation of glycosylation- and acylation-induced shifts in the ${ }^{13} \mathrm{C}$ NMR spectrum at $\delta_{\mathrm{C}} 88.7$ (downfield shift of C-3), $\delta_{\mathrm{C}}$ 76.5 (downfield shift of C-21), and $\delta_{\mathrm{C}} 174.4$ (upfield shift of C-28).

The ${ }^{1} \mathrm{H}$ NMR spectrum of $\mathbf{1}$ displayed signals for seven anomeric protons at $\delta_{\mathrm{H}} 6.06(\mathrm{br} \mathrm{s}), 5.83(\mathrm{~d}, \mathrm{~J}=7.5 \mathrm{~Hz})$, 5.77 (br s), 5.10 (d, J = 7.5 Hz), 4.91 (d, J = 7.5 Hz), 4.90 $(\mathrm{d}, \mathrm{J}=7.8 \mathrm{~Hz})$, and $4.79(\mathrm{~d}, \mathrm{~J}=8.0 \mathrm{~Hz})$, which correlated with the carbon signals at $\delta_{\mathrm{C}} 109.8,94.9,101.2,104.7$, 103.8, 105.6, and 102.5, respectively, in the HSQC spectrum. Starting from the anomeric proton of each sugar unit, all the protons within each spin system were delineated using COSY with the aid of TOCSY and NOESY spectra. After assignments of the protons, the ${ }^{13} \mathrm{C}$ NMR resonances of each sugar unit were identified by HSQC and further confirmed by HMBC. The COSY and TOCSY spectra 


\section{Chart 1}

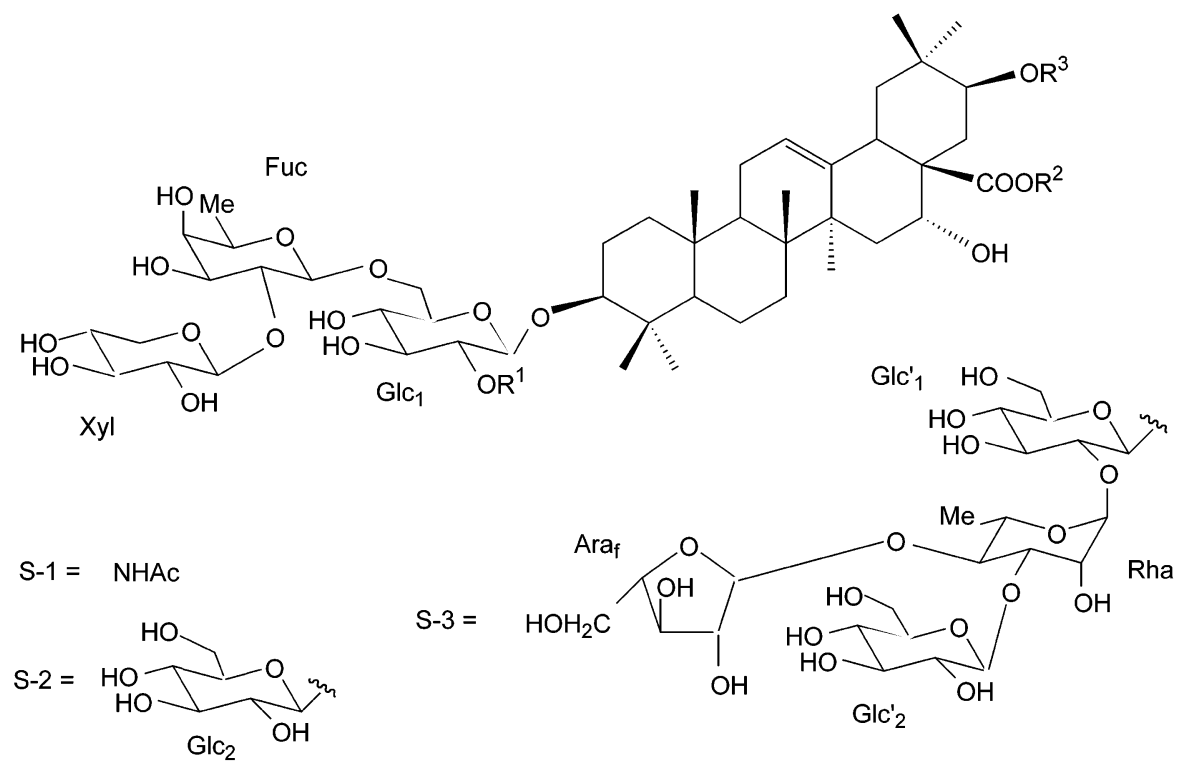

$\begin{array}{lccc} & \mathrm{R}^{1} & \mathrm{R}^{2} & \mathrm{R}^{3} \\ \mathbf{1} & \mathrm{S}-1 & \mathrm{~S}-3 & \mathrm{~S}-4 \\ \mathbf{3} & \mathrm{S}-2 & \mathrm{~S}-3 & \mathrm{~S}-4 \\ \mathbf{4} & \mathrm{S}-2 & \mathrm{H} & \mathrm{S}-5 \\ \mathbf{5} & \text { S-1 } & \text { H } & \mathrm{H} \\ & \mathrm{S}-2 & \mathrm{H} & \mathrm{H}\end{array}$

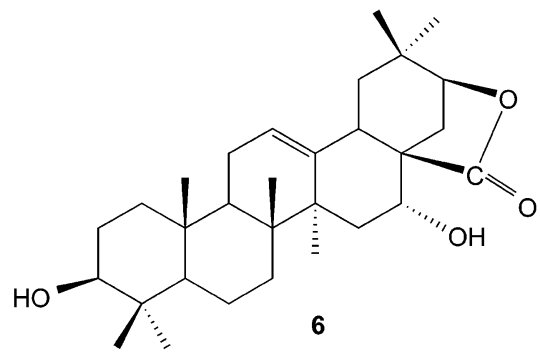<smiles>O=C(C=S)c1ccccc1O</smiles>

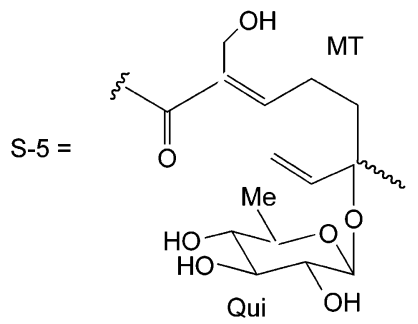

indicated the presence of seven monosaccharide units, and one of them was an $\alpha$-rhamnopyranosyl (Rha) from its typical pattern in the COSY-LR spectrum..$^{8,9}$ After interpretation of the ${ }^{1 \mathrm{H}}$ and ${ }^{13} \mathrm{C}$ NMR signals, the other sugars were identified as two $\beta$-glucopyranosyl (Glc) units, one $\beta$-fucopyranosyl (Fuc) unit, one $\beta$-xylopyranosyl (Xyl) unit, one 2-(acetylamino)-2-deoxy- $\beta$-glucopyranosyl (GlcNAc) unit, and one arabinofuranosyl unit, respectively. The $\alpha$-configuration of this latter sugar was clarified by observation of NOESY correlations between $\mathrm{H}-1, \mathrm{H}-3$, and $\mathrm{H}-5$. The absolute configurations of these sugar residues were determined to be D-glucose, D-xylose, D-fucose, L-rhamnose, L-arabinose, and 2-(acetylamino)-2-deoxy- $\beta$-D-glucopyranose by GC analysis of chiral derivatives of sugars in the acid hydrolysate (see Experimental Section). ${ }^{10}$
The ${ }^{1} \mathrm{H}$ and ${ }^{13} \mathrm{C}$ NMR signals of 1 assigned from the $2 \mathrm{D}$ NMR experiments were al most superimposable with those of 4, previously characterized as acacic acid 3-O- $\beta$-Dxyl opyranosyl-( $1 \rightarrow 2)-\beta$-D-fucopyranosyl-( $1 \rightarrow 6)$-2-(acetylamino)-2-deoxy- $\beta$-D-gl ucopyranoside, except for the presence of the additional salicylic acid unit ${ }^{7}$ and an oligosaccharidic chain at C-28.

The assignments of the ${ }^{1} \mathrm{H}$ and ${ }^{13} \mathrm{C}$ NMR signals of $\mathbf{1}$ from the TOCSY, HSQC, and HMBC spectra showed that the four remaining sugars were a terminal $\mathrm{Glc}\left(\mathrm{GlC}_{2}^{\prime}\right)$, a disubstituted Glc (Glc-1,2)(Glc' $\left.{ }_{1}\right)$, a terminal Araf, and a trisubstituted Rha (Rha-1,3,4). A correlation in the HSQC spectrum at $\delta_{\mathrm{C}} / \delta_{\mathrm{H}} 94.9 / 5.83(\mathrm{~d}, \mathrm{~J}=7.5 \mathrm{~Hz})$ showed that the $\mathrm{GIC}_{1}^{\prime}$ residue is linked to the carboxylic group of the aglycon by an ester linkage. This condusion was supported 
by the upfield shift of C-28 at $\delta_{\mathrm{C}} 174.4$, in comparison with

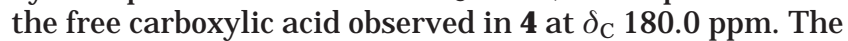
long-range correlations observed in the HMBC spectrum between the ${ }^{1} \mathrm{H}$ NMR signals at $\delta_{\mathrm{H}}$ (Rha-1) 5.77 and the ${ }^{13} \mathrm{C}$ NMR signals at $\delta_{\mathrm{C}}\left(\mathrm{GIC}^{\prime}{ }_{1}-2\right) 76.9$, between $\delta_{\mathrm{H}}\left(\mathrm{GIC}^{\prime}{ }_{2}-1\right)$ 5.10 and $\delta_{\mathrm{C}}$ (Rha-3) 81.2, and between $\delta_{\mathrm{H}}$ (Araf-1) 6.06 and $\delta_{\mathrm{C}}$ (Rha-4) 77.6 showed that the tetrasaccharide residue O-a-L-arabinofuranosyl-( $1 \rightarrow 4)$-[ $\beta$-D-gl ucopyranosyl-( $1 \rightarrow 3)$ ]a-L-rhamnopyranosyl-( $1 \rightarrow 2)-\beta$-D-glucopyranosyl was linked to the acacic acid unit at C-28.

The comparison of the ${ }^{13} \mathrm{C}$ NMR chemical shifts of $\mathbf{4}$ and 1 permitted the position of the linkage of the salicylic acid on the aglycon to be located. In $\mathbf{1}$, when compared to $\mathbf{4}$, the signals for C-20, C-21, and C-22 were displayed upfield by $-2.1 \mathrm{ppm}$, downfield by $+2.6 \mathrm{ppm}$, and upfield by -6.5 ppm, respectively, as a consequence of the acylation at C-21.

From these data, compound 1 was assigned as $16 \alpha-$ hydroxy-21 $\beta$-[(2-hydroxybenzoyl )oxy]-3 $\beta$-[(O- $\beta$-D-xylopyranosyl-(1 $\rightarrow 2$ )-O- $\beta$-D-fucopyranosyl-(1 $\rightarrow 6)-2$-(acetylamino)-2deoxy- $\beta$-D-glucopyranosyl)oxy]ol ean-12-en-28-oic acid 28$\mathrm{O}-\alpha$-L-arabinofuranosyl-( $1 \rightarrow 4)$-O-[ $\beta$-D-glucopyranosyl-( $1 \rightarrow 3)$ ]O- $\alpha$-L-rhamnopyranosyl-(1 $\rightarrow 2)-\beta$-D-glucopyranosyl ester. Compound $\mathbf{1}$ is a new compound ${ }^{11,17-25}$ and was given the trivial name adianthifolioside $A$.

Compound $\mathbf{2}$ was obtained as an amorphous powder. HRESIMS (positiveion mode) exhibited a quasimolecular ion peak at $\mathrm{m} / \mathrm{z} 1835.7700[\mathrm{M}+\mathrm{Na}]^{+}$(calcd 1835.7727), consistent with a molecular formula of $\mathrm{C}_{83} \mathrm{H}_{128} \mathrm{O}_{43}$. U pon acid hydrolysis with $2 \mathrm{~N}$ TFA at $120{ }^{\circ} \mathrm{C}, \mathbf{2}$ afforded the aglycon 6, again identified as acacic acid lactone by comparison of its ${ }^{11} \mathrm{H}$ and ${ }^{13} \mathrm{C}$ NMR data with those reported. ${ }^{6}$ The sugars obtained from the saponin hydrolysate were identified as glucose, fucose, rhamnose, arabinose, and xylose, by comparison with authentic samples on TLC. Alkaline hydrolysis of $\mathbf{2}$ afforded salicylic acid (7), identified by comparison of its ${ }^{1} \mathrm{H}$ and ${ }^{13} \mathrm{C}$ NMR data with those reported, ${ }^{7}$ and a prosapogenin (5), whose NMR data were al most similar to those of the prosapogenin previously isolated from the alkaline hydrolysate of the Al bizia cortex saponin mixture. ${ }^{12}$ The above data suggested that 2 should be a 21-acyl-3,28-0-bisdesmoside. This was confirmed by the observation of glycosylation- and acylation-induced shifts in the ${ }^{13} \mathrm{C} N$ MR spectrum at $\delta_{\mathrm{C}} 88.8$ (downfield shift of C-3), $\delta_{C} 76.1$ (downfield shift of C-21), and $\delta_{C} 174.5$ (upfield shift of C-28).

The ${ }^{1 H}$ NMR spectrum of $\mathbf{2}$ displayed signals for eight anomeric protons at $\delta_{\mathrm{H}} 6.09(\mathrm{br} \mathrm{s}), 5.85(\mathrm{~d}, \mathrm{~J}=7.5 \mathrm{~Hz}$ ), $5.72(\mathrm{br} \mathrm{s}), 5.30(\mathrm{~d}, \mathrm{~J}=7.5 \mathrm{~Hz}), 5.10(\mathrm{~d}, \mathrm{~J}=7.5 \mathrm{~Hz}), 4.90$ $(\mathrm{d}, \mathrm{J}=7.8 \mathrm{~Hz}), 4.80(\mathrm{~d}, \mathrm{~J}=8.0 \mathrm{~Hz})$, and $4.72(\mathrm{~d}, \mathrm{~J}=7.5$ $\mathrm{Hz}$ ), which correlated with the ${ }^{13} \mathrm{C}$ NMR signals at $\delta_{\mathrm{C}} 109.8$, $94.8,101.3,103.8,104.7,105.6,102.5$, and 104.2, respectively, in the HSQC spectrum. Evaluation of spin-spin couplings and chemical shifts and interpretation of extensive 2D NMR allowed the identification of four $\beta$-glucopyranosyl units, one $\beta$-fucopyranosyl unit, one $\beta$-xylopyranosyl unit, one $\alpha$-rhamnopyranosyl unit, and one $\alpha$-arabinofuranosyl unit, respectively. The absolute configuration of sugar residues was determined to be D-glucose, D-xylose, D-fucose, L-rhamnose, and L-arabinose by GC analysis of chiral derivatives of sugars in the acid hydrolysate (see Experimental Section). ${ }^{10}$

Almost all NMR signals of $\mathbf{2}$ (Tables 1 and 2) were superimposable on those of $\mathbf{1}$ except for those of the oligosaccharidic moiety linked at C-3. The signals of this chain assigned from $2 \mathrm{D} N \mathrm{NMR}$ experiments were almost superimposable with those of the 3-O- $\beta$-D-xylopyranosyl-
Table 1. ${ }^{13} \mathrm{C}$ NMR and ${ }^{1} \mathrm{H}$ NMR Data of the Aglycons of $\mathbf{1}$ and $2\left(\mathrm{C}_{5} \mathrm{D}_{5} \mathrm{~N}\right)^{\mathrm{a}, \mathrm{b}}$

\begin{tabular}{|c|c|c|c|c|c|}
\hline \multirow[b]{2}{*}{ position } & \multirow[b]{2}{*}{ DEPT } & \multicolumn{2}{|r|}{1} & \multicolumn{2}{|r|}{2} \\
\hline & & $\delta_{\mathrm{C}}$ & $\delta_{\mathrm{H}}$ & $\delta_{\mathrm{C}}$ & $\delta_{\mathrm{H}}$ \\
\hline 1 & $\mathrm{CH}_{2}$ & 38.0 & $0.94,1.52$ & 38.0 & $0.94,1.51$ \\
\hline 2 & $\mathrm{CH}_{2}$ & 26.2 & $\mathrm{nd}^{\mathrm{c}}$, nd & & \\
\hline 3 & $\mathrm{CH}$ & 88.7 & 3.29 & 88.8 & 3.30 \\
\hline 4 & C & 39.0 & & 39.6 & \\
\hline 5 & $\mathrm{CH}$ & 55.8 & 0.84 & 55.1 & 0.77 \\
\hline 6 & $\mathrm{CH}_{2}$ & 18.2 & 1.33 , nd & 18.3 & nd, nd \\
\hline 7 & $\mathrm{CH}_{2}$ & 33.3 & 1.66 , nd & 32.8 & 1.57 , nd \\
\hline 8 & C & 40.1 & & 39.5 & \\
\hline 9 & $\mathrm{CH}$ & 46.9 & 1.78 & 46.1 & 1.73 \\
\hline 10 & C & 36.8 & & 37.0 & \\
\hline 11 & $\mathrm{CH}_{2}$ & 23.3 & $1.95, \mathrm{nd}$ & 22.8 & $1.94, \mathrm{nd}$ \\
\hline 12 & $\mathrm{CH}$ & 122.7 & 5.57 & 122.7 & 5.57 \\
\hline 13 & C & 143.0 & & 142.7 & \\
\hline 14 & C & 41.2 & & 41.5 & \\
\hline 15 & $\mathrm{CH}_{2}$ & 35.1 & $1.91,2.09$ & 34.8 & $1.90,2.11$ \\
\hline 16 & $\mathrm{CH}$ & 73.1 & 5.07 & 73 & 5.08 \\
\hline 17 & C & 51.4 & & 51.2 & \\
\hline 18 & $\mathrm{CH}$ & 40.3 & 3.27 & 41.3 & 3.38 \\
\hline 19 & $\mathrm{CH}_{2}$ & 47.3 & $1.33,2.82$ & 47.3 & 1.30 \\
\hline 20 & C & 35.2 & & 34.8 & \\
\hline 21 & $\mathrm{CH}$ & 76.5 & 6.09 & 76.1 & 6.10 \\
\hline 22 & $\mathrm{CH}_{2}$ & 35.7 & $2.13,2.68$ & & \\
\hline 23 & $\mathrm{CH}_{3}$ & 27.5 & 1.08 & 27.5 & 1.13 \\
\hline 24 & $\mathrm{CH}_{3}$ & 16.5 & 0.88 & 16.7 & 1.06 \\
\hline 25 & $\mathrm{CH}_{3}$ & 15.2 & 0.82 & 15.3 & 0.87 \\
\hline 26 & $\mathrm{CH}_{3}$ & 16.8 & 1.02 & 16.9 & 1.02 \\
\hline 27 & $\mathrm{CH}_{3}$ & 26.7 & 1.73 & 26.7 & 1.73 \\
\hline 28 & $\mathrm{COOH}$ & 174.4 & & 174.5 & \\
\hline 29 & $\mathrm{CH}_{3}$ & 28.6 & 0.88 & 28.7 & 0.85 \\
\hline 30 & $\mathrm{CH}_{3}$ & 18.7 & 1.02 & 18.7 & 1.03 \\
\hline
\end{tabular}

a Multiplicities were assigned from DEPT spectra. ${ }^{\mathrm{b}}$ Assignments were based on the HMBC, HSQC, and DEPT experiments (150 M Hz for ${ }^{13} \mathrm{C}$ and $600 \mathrm{MHz}$ for ${ }^{1} \mathrm{H}$ NMR). ${ }^{\mathrm{c}}$ nd: not determined.

$(1 \rightarrow 2)-\beta$-D-fucopyranosyl-( $1 \rightarrow 6)$-[ $\beta$-D-glucopyranosyl-( $1 \rightarrow 2)$ ]$\beta$-D-glucopyranose moiety of $\mathbf{3}$ and $\mathbf{5}$. Thus, compound $\mathbf{2}$ was concluded to be 16 $\alpha$-hydroxy-21 $\beta$-[(2-hydroxybenzoyl)oxy]-3 $\beta$-[(O- $\beta$-D-glucopyranosyl-(1 $\rightarrow 2)-\mathrm{O}-[\mathrm{O}-\beta$-D-xylopyranos-

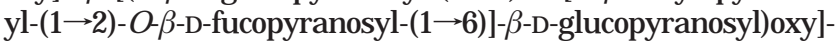
ol ean-12-en-28-oic acid 28-O- $\alpha$-L-arabinofuranosyl-(1 $\rightarrow 4$ O-[ $\beta$-D-glucopyranosyl-(1 $\rightarrow 3)$ ]-O- $\alpha$-L-rhamnopyranosyl-( $1 \rightarrow 2)$ $\beta$-D-gl ucopyranosyl ester. As a new compound, ${ }^{11,17-25} \mathbf{2}$ was given the trivial name adianthifolioside B. It is interesting to note that $\mathbf{1}$ and $\mathbf{2}$ contain a salicilyl substituent, not reported before among plant triterpene glycosides.

Since triterpene saponins from plants have been reported to exert immunostimulatory activities, ${ }^{11,13}$ the CSM and compounds 1-4 were tested in an in vitro lymphocyte proliferation assay. ${ }^{14}$ The cellular proliferation was measured by ${ }^{3} \mathrm{H}$-thymidine incorporation in J urkat tumor cell lines (human T cell leukemia). Compound $\mathbf{2}$ showed a concentration-dependent immunomodulatory effect ( $F$ igure 1). At a concentration of $10^{-2} \mu \mathrm{M}$, compound $\mathbf{2}$ exerted a weak but significant lymphoproliferative activity with a stimulation index (SI) of 1.21 , and at $1 \mu \mathrm{M}$ it showed an inhibition of this effect. Furthermore, 1 and the CSM displayed a cytotoxic effect to lymphocytes in culture (from $1 \mu \mathrm{M}$ for 1). Compound $\mathbf{3}$ showed a weak cytotoxic effect from $5 \mu \mathrm{M}$, whereas 4 exhibited a lymphoprol iferative effect in the concentration range $1-10 \mu \mathrm{M}$ and no cytotoxic effect at all tested concentrations.

In addition, the hemolytic activities of the CSM and compounds 1-4 were evaluated on sheep erythrocytes according to a procedure adapted from the litterature..$^{15}$ Strong hemolytic activity is considered to be a typical characteristic of saponins, although some saponins show only weak or no hemolytic effect at all. This activity is often 
Table 2. ${ }^{1} \mathrm{H}$ and ${ }^{13} \mathrm{C}$ NMR Data of Sugar and Acid Moieties of Compounds $\mathbf{1}$ and $\mathbf{2}\left(\mathrm{C}_{5} \mathrm{D}_{5} \mathrm{~N}\right)^{\mathrm{a}, \mathrm{b}}$

\begin{tabular}{|c|c|c|c|c|c|c|c|c|c|c|c|c|}
\hline \multirow[b]{2}{*}{ position } & \multicolumn{3}{|c|}{1} & & \multicolumn{3}{|c|}{2} & & \multicolumn{2}{|l|}{1} & \multicolumn{2}{|l|}{2} \\
\hline & & $\delta_{\mathrm{H}}$ & $\delta_{\mathrm{C}}$ & & & $\delta_{\mathrm{H}}$ & $\delta_{\mathrm{C}}$ & & $\delta_{\mathrm{H}}$ & $\delta_{\mathrm{C}}$ & $\delta_{\mathrm{H}}$ & $\delta_{\mathrm{C}}$ \\
\hline 3-O-sugar & & & & & & & & 28-0-sugar & & & & \\
\hline Glc $N A C-1$ & $4.91(d, J$ & $=7.5 \mathrm{~Hz})$ & 103.8 & $\mathrm{GlC}_{1}-1$ & $4.72(d, J)$ & $=7.5 \mathrm{~Hz})$ & 104.2 & $\mathrm{G} \mid \mathrm{c}_{1}^{\prime}-1$ & $5.83(\mathrm{~d}, \mathrm{~J}=7.5 \mathrm{~Hz})$ & 94.9 & $5.85(\mathrm{~d}, \mathrm{~J}=7.5 \mathrm{~Hz})$ & 94.8 \\
\hline 2 & 4.40 & & 56.8 & 2 & 4.17 & & 80.3 & 2 & 3.90 & 76.9 & 3.89 & 75.5 \\
\hline 3 & 4.30 & & 74.5 & 3 & 3.88 & & 77.9 & 3 & 3.83 & 78.1 & 3.87 & 77.0 \\
\hline 4 & 3.93 & & 73.1 & 4 & 3.91 & & 71.0 & 4 & 3.91 & 70.5 & 3.92 & 70.6 \\
\hline 5 & 3.90 & & 75.0 & 5 & 4.04 & & 77.1 & 5 & 3.84 & 78.9 & 3.84 & 78.2 \\
\hline \multirow[t]{2}{*}{6} & 4.19 & & 69.0 & 6 & 4.20 & & 68.7 & 6 & 4.00 & 61.2 & 4.00 & 61.6 \\
\hline & 4.50 & & & & 4.49 & & & & 4.23 & & 4.21 & \\
\hline $\mathrm{NHCOCH}_{3}$ & $8.91(d, J$ & $=8.8 \mathrm{~Hz}$ & 171.9 & & & & & & & & & \\
\hline $\mathrm{NHCOCH}_{3}$ & 2.13 & & 22.9 & & & & & & & & & \\
\hline Fuc-1 & $4.79(\mathrm{~d}, \mathrm{~J}$ & $=8.0 \mathrm{~Hz})$ & 102.5 & $\mathrm{Glc}_{2}-1$ & $5.30(\mathrm{~d}, \mathrm{~J}$ & $=7.5 \mathrm{~Hz})$ & 103.8 & Rha-1 & 5.77 (brs) & 101.2 & 5.72 (brs) & 101.3 \\
\hline 2 & 4.25 & & 80.8 & 2 & 3.92 & & 76.3 & 2 & 4.98 & 69.8 & 4.99 & 69.9 \\
\hline 3 & 3.90 & & 74.5 & 3 & 3.83 & & 78.1 & 3 & 4.65 & 81.2 & 4.69 & 81.2 \\
\hline 4 & 3.92 & & 71.4 & 4 & 4.06 & & 70.1 & 4 & 4.33 & 77.6 & 4.33 & 77.7 \\
\hline 5 & 3.65 & & 70.7 & 5 & 4.07 & & 77.1 & 5 & 4.32 & 68.6 & 4.34 & 68.7 \\
\hline 6 & 1.37 & & 16.4 & 6 & $\begin{array}{l}4.08 \\
4.30\end{array}$ & & 61.2 & 6 & 1.65 & 18.2 & 1.66 & 18.4 \\
\hline Xyl-1 & $4.90(d, J$ & $=7.8 \mathrm{~Hz})$ & 105.6 & Fuc-1 & $4.80(d, J$ & $=8.0 \mathrm{~Hz})$ & 102.5 & $\mathrm{Ara}_{\mathrm{f}}-1$ & 6.06 (brs) & 109.8 & 6.09 (brs) & 109.8 \\
\hline 2 & 4.01 & & 74.1 & 2 & 4.26 & & 80.9 & 2 & 4.79 & 83.1 & 4.80 & 83.2 \\
\hline 3 & 4.03 & & 77.1 & 3 & 4.08 & & 74.1 & 3 & 4.58 & 77.4 & 4.55 & 77.6 \\
\hline 4 & 4.08 & & 70.7 & 4 & 3.98 & & 73.0 & 4 & 4.56 & 84.4 & 4.56 & 84.4 \\
\hline \multirow[t]{16}{*}{5} & 3.48 & & 66.2 & 5 & 3.66 & & 71.0 & 5 & 4.10 & 61.4 & 4.10 & 61.7 \\
\hline & 4.33 & & & 6 & 1.37 & & 16.4 & & 4.32 & & 4.35 & \\
\hline & & & & Xyl-1 & $4.90(d, J)$ & $=7.8 \mathrm{~Hz})$ & 105.6 & $\mathrm{GIC}_{2}^{\prime}-1$ & $5.10(\mathrm{~d}, \mathrm{~J}=7.5 \mathrm{~Hz})$ & 104.7 & $5.10(\mathrm{~d}, \mathrm{~J}=7.5 \mathrm{~Hz})$ & 104.7 \\
\hline & & & & 2 & 3.89 & & 74.4 & 2 & 3.89 & 74.5 & 3.90 & 74.4 \\
\hline & & & & 3 & 4.03 & & 77.3 & 3 & 4.32 & 79.9 & 4.30 & 79.3 \\
\hline & & & & 4 & 4.05 & & 69.8 & 4 & 4.34 & 70.3 & 4.10 & 70.6 \\
\hline & & & & 5 & 3.50 & & 66.1 & 5 & 3.81 & 77.4 & 4.05 & 77.1 \\
\hline & & & & & 4.16 & & & 6 & 4.05 & 61.3 & 4.07 & 61.5 \\
\hline & & & & & & & & & 4.30 & & 4.33 & \\
\hline & & & & & & & & 21-O- acyl & & 110.1 & & 110.2 \\
\hline & & & & & & & & $\frac{1}{2}$ & & 151.7 & & 151.8 \\
\hline & & & & & & & & 3 & 6.62 & 115.4 & 6.62 & 115.4 \\
\hline & & & & & & & & 4 & 7.24 & 134.2 & 7.25 & 134.1 \\
\hline & & & & & & & & 5 & 7.03 & 117.0 & 7.04 & 116.8 \\
\hline & & & & & & & & 6 & 7.83 & 130.9 & 7.86 & 131.0 \\
\hline & & & & & & & & 7 & & 167.9 & & 167.9 \\
\hline
\end{tabular}

a Assignments were based on COSY, TOCSY, NOESY, HSQC, and HMBC experiments (150 MHz for ${ }^{13} \mathrm{C}$ and $600 \mathrm{MHz}$ for ${ }^{1} \mathrm{H}$ NMR). Multiplicities were assigned from DEPT spectra. Coupling constants in $\mathrm{Hz}$. Overlapped signals are reported without designated multiplicities. ${ }^{b}{ }^{1} \mathrm{H}$ and ${ }^{13} \mathrm{C}$ chemical shifts of substituted residues are italicized.

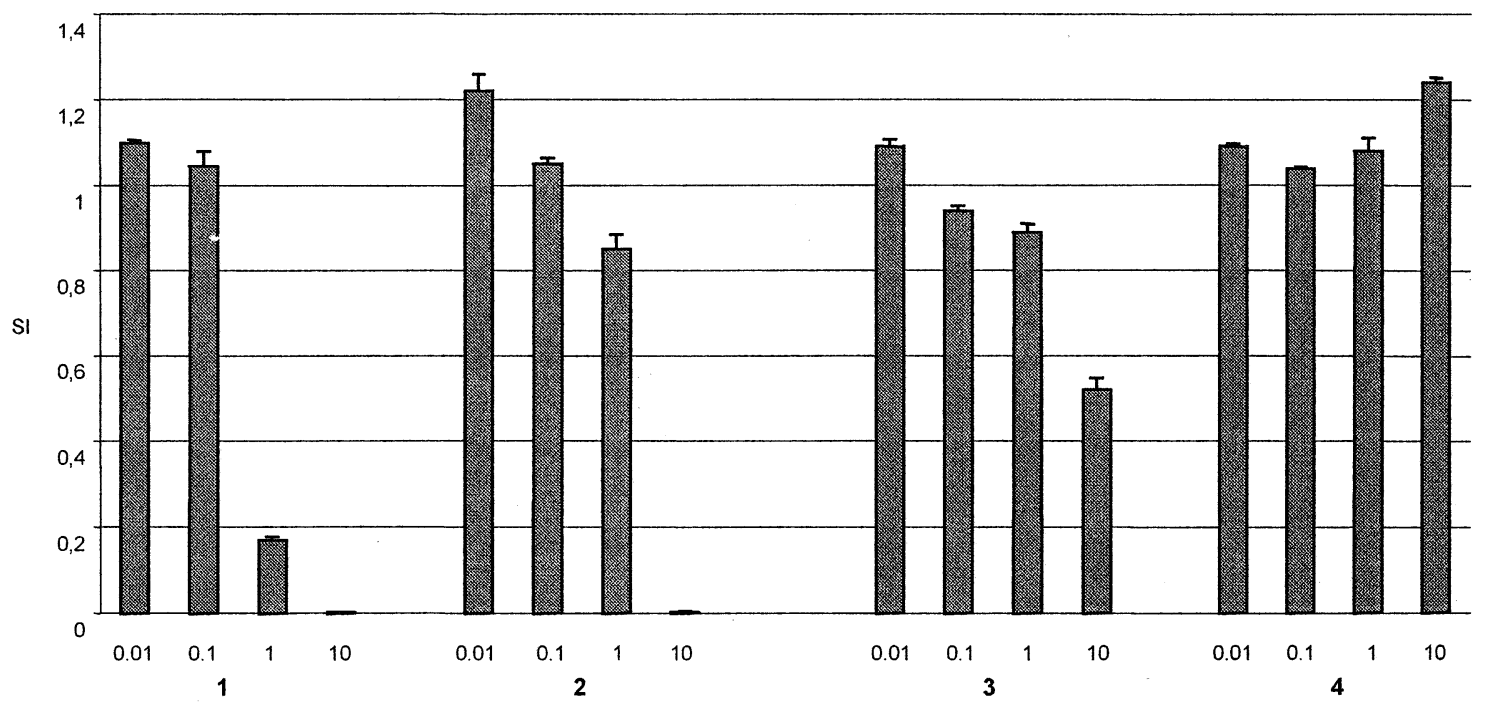

Figure 1. Effect of compounds 1-4 on the cellular proliferation of J urkat cells measured by ${ }^{3 \mathrm{H}}$-thymidine incorporation (see Experimental Section). $\mathrm{SI}=$ stimulation index. Each column represents the mean $\pm \mathrm{SE}(\mathrm{n}=4)$.

related to the amphiphilic character of the saponin and is influenced by the affinity of the aglycon to cholesterol in cell membranes, allowing the formation of pores. In this test, since the CSM was shown to exhibit a good hemolytic activity $\left(\mathrm{HC}_{50}=12 \mu \mathrm{g} / \mathrm{mL}\right)$, we have tested the pure compounds. Among them, 1 exhibited the highest hemolytic activity $\left(\mathrm{HD}_{50}=17.5 \mu \mathrm{g} / \mathrm{mL}\right)$, followed by 2 , which was less active than $\mathbf{1}\left(\mathrm{HD}_{50}=48 \mu \mathrm{g} / \mathrm{mL}\right)$, whereas $\mathbf{3}$ and 4 were not hemolytic at the concentration tested $\left(\mathrm{HD}_{50}>400 \mu \mathrm{g} /\right.$ $\mathrm{mL}$ ). These data suggested the importance of the $\mathrm{N}$ acetamido group in $\mathbf{1}$ for the hemolytic activity compared with 2. The results of this above test correlated well with 
those of the cytotoxicity observed for $\mathbf{1}$ and $\mathbf{2}$ against J urkat cells in the concentration range 1-10 $\mu \mathrm{M}$. Moreover, concerning 3, which is not hemolytic up to $400 \mu \mathrm{g} / \mathrm{mL}$ (282 $\mu \mathrm{M})$ but cytotoxic from $10 \mu \mathrm{M}$, it could be thought that another mechanism than the membrane effect is at the origin of the cytotoxicity. Since avicins (dosely related to 3) were shown to induce inhibition of the J urkat cell proliferation by induction of apoptosis, ${ }^{16}$ we are currently investigating this possible mechanism involved in the cytotoxic effect of $\mathbf{3}$ against J urkat T cells.

\section{Experimental Section}

General Experimental Procedures. Optical rotations were taken with a Perkin-E Imer 241 polarimeter. IR spectra ( $\mathrm{KBr}$ disks) were recorded on a Perkin-Elmer 281 spectrophotometer. The 1D and 2D NMR spectra $\left({ }^{1} \mathrm{H}-{ }^{1} \mathrm{H}\right.$ COSY, TOCSY, NOESY, HSQC, and HMBC) were performed using a UNITY 600 spectrometer at the operating frequency of $600 \mathrm{M} \mathrm{Hz}$ on a Varian INOVA 600 instrument equipped with a SUN $4 \mathrm{~L}-\mathrm{X}$ computer system $\left(600 \mathrm{MHz}\right.$ for ${ }^{1} \mathrm{H}$ and $150 \mathrm{MHz}$ for ${ }^{13} \mathrm{C}$ spectra). Conventional pulse sequences were used for COSY, HSQC, and HMBC. TOCSY spectra were acquired using the standard MLEV17 spin-locking sequence and $90 \mathrm{~ms}$ mixing time. The mixing time in the NOESY experiment was set to $500 \mathrm{~ms}$. The carbon type $\left(\mathrm{CH}_{3}, \mathrm{CH}_{2}, \mathrm{CH}\right)$ was determined by DEPT experiments. All chemical shifts $(\delta)$ are given in ppm, and the samples were solubilized in pyridine $d_{5}\left(\delta_{c} 150.3\right.$, 155.9, 123.9). The fast-atom bombardment mass spectrum (FABMS) (negative-ion mode, thioglycerol matrix) was obtained on a J EOL SX 102 mass spectrometer. HRESIMS was carried out on a Q-TOF 1 micromass spectrometer. GC analysis was carried out on a Termoquest gas chromatograph using a DB-1701 capillary column $(30 \mathrm{~m} \times 0.25 \mathrm{~mm}$, i.d.) $(\mathrm{J} \& \mathrm{~W}$ Scientific); detection, FID; detector temperature, $250{ }^{\circ} \mathrm{C}$; injection temperature, $230^{\circ} \mathrm{C}$; initial temperature was maintained at $80^{\circ} \mathrm{C}$ for $5 \mathrm{~min}$ and then raised to $270^{\circ} \mathrm{C}$ at the rate of $15{ }^{\circ} \mathrm{C} / \mathrm{min}$; carrier gas, He. TLC and HPTLC employed precoated Si gel plates $60 \mathrm{~F}_{254}$ (Merck). The following TLC solvent systems were used: for saponins (a) $\mathrm{CHCl}_{3}-\mathrm{MeOH}-$ $\mathrm{AcOH}-\mathrm{H}_{2} \mathrm{O}, 15: 8: 3: 2$, (b) $\mathrm{CHCl}_{3}-\mathrm{MeOH}-\mathrm{H}_{2} \mathrm{O}, 65: 40: 10$; for sapogenins (c) toluene- $\mathrm{Me}_{2} \mathrm{CO}, 4: 1$; for monosaccharides (d) $\mathrm{CHCl}_{3}-\mathrm{MeOH}-\mathrm{H}_{2} \mathrm{O}$, 8:5:1. Spray reagents for the saponins were Komarowsky reagent, a mixture (5:1) of p-hydroxybenzaldehyde (2\% in $\mathrm{MeOH})$ and $\mathrm{H}_{2} \mathrm{SO}_{4} 50 \%$; for the sugars, diphenylaminephosphoric acid reagent. I solations were carried out using a medium-pressure liquid chromatography (MPLC) system [Gilson pump M 305, head pump 25 SC, manometric module M 805, Autoinjector 234, Büchi column $(460 \times 25 \mathrm{~mm}$ and $460 \times 15 \mathrm{~mm})$, Büchi precol umn $(110 \times 15 \mathrm{~mm})$ ].

Plant Material. The roots of Albizia adianthifolia (Schumach.) W. F. Wight (Mimosaceae) were collected in A pril 1990 at Lamto, Ivory Coast, and identified by Mr. N. Konan, Tropical Ecology Station, Lamto. A voucher specimen (No. 1690) is deposited in the Herbarium of the Laboratory of Pharmacognosy, Faculty of Pharmacy, University of Burgundy, France.

Extraction and I solation. Dried, powdered roots (200 g) were macerated for $4 \mathrm{~h}$ with $3 \mathrm{~L}$ of $95 \%$ ethanol and further refluxed for $24 \mathrm{~h}(3 \times 3 \mathrm{~L})$. After cooling, the ethanolic solution was filtrated and evaporated to dryness, and the $95 \%$ ethanolic extract was obtained $(20 \mathrm{~g})$. This extract was suspended in $\mathrm{H}_{2} \mathrm{O}(400 \mathrm{~mL})$ and submitted to a partition against n-BuOH saturated with $\mathrm{H}_{2} \mathrm{O}(3 \times 400 \mathrm{~mL})$. After evaporation under reduced pressure of the solvent, $7 \mathrm{~g}$ of a n- $\mathrm{BuOH}$ extract was obtained. This was solubilized in $\mathrm{MeOH}(10 \mathrm{~mL})$ and precipitated in $\mathrm{Et}_{2} \mathrm{O}(3 \times 250 \mathrm{~mL})$, yielding $2.5 \mathrm{~g}$ of a crude saponin fraction. This resulting mixture was suspended in water, dialyzed for 2 days, and lyophilized, yielding a crude saponin mixture (CSM). An aliquot (1.8 g) of this mixture was fractionated by column chromatography over Sephadex LH-20 and submitted to repeated MPLC column chromatography on $\mathrm{Si}$ gel $60(15-40 \mu \mathrm{m})$ using as eluent $\mathrm{CHCl}_{3}-\mathrm{MeOH}-\mathrm{H}_{2} \mathrm{O}(8: 5: 1$ and 6:4:1), affording compounds 1 (13 mg) and 2 (14 mg).

Adianthifolioside A (1): white amorphous powder; $[\alpha]^{20} \mathrm{D}$ $-20^{\circ}$ (c 0.1, MeOH); I R ( $\left.\mathrm{K} \mathrm{Br}\right) v_{\max } 3500-3300(\mathrm{OH}), 2928(\mathrm{CH})$, 1735 ( $\mathrm{C}=\mathrm{O}$ ester), 1718 ( $\mathrm{C}=\mathrm{O}$ carboxylic acid), 1570 and 1639 (CO-NH), 1580, 1260, $1090 \mathrm{~cm}^{-1}$; ${ }^{1} \mathrm{H}$ NMR (pyridine- ${ }_{5}, 600$ $\mathrm{MHz}$ ) and ${ }^{13} \mathrm{C}$ NMR (pyridine- $d_{5}, 150 \mathrm{MHz}$ ), see Tables 1 and 2; long-range correlations in the HMBC spectrum used for defining the aglycon, as previously reported; ${ }^{5}$ negative FABMS (glycerol matrix) m/z $1690\left[\mathrm{M}-\mathrm{H}^{-}, 1088[(\mathrm{M}-\mathrm{H})-162-\right.$ $132-146-162]^{-} ;$HRESIMS positive mode $\mathrm{m} / \mathrm{z} 1714.7490$ $[\mathrm{M}+\mathrm{Na}]^{+}$(calcd for $\mathrm{C}_{79} \mathrm{H}_{121} \mathrm{NO}_{38} \mathrm{Na}$, 1714.7465); TLC R 0.29 (system b), brown spot by spraying with Komarowsky reagent.

Adianthifolioside B (2): white amorphous powder; $[\alpha]^{20} \mathrm{D}$ $-20^{\circ}$ (c 0.1, MeOH); I R ( $\left.\mathrm{K} \mathrm{Br}\right) v_{\max } 3500-3300(\mathrm{OH}), 2927(\mathrm{CH})$, 1735 ( $\mathrm{C}=\mathrm{O}$ ester ), 1718 ( $\mathrm{C}=\mathrm{O}$ carboxylic acid), 1580, 1260, $1090 \mathrm{~cm}^{-1}$; ${ }^{1} \mathrm{H}$ NMR (pyridine $\mathrm{d}_{5}, 600 \mathrm{MHz}$ ) and ${ }^{13} \mathrm{C} \mathrm{NMR}$ (pyridine $_{5}, 150 \mathrm{MHz}$ ), see Tables 1 and 2; long-range correlations in the HMBC spectrum used for defining the aglycon, as previously reported; 5 negative FABMS (glycerol matrix) $\mathrm{m} / \mathrm{z} 1811\left[\mathrm{M}-\mathrm{H}^{-}\right.$; HRESIMS positive mode $\mathrm{m} / \mathrm{z}$ $1835.7700[\mathrm{M}+\mathrm{Na}]^{+}$(calcd for $\mathrm{C}_{83} \mathrm{H}_{128} \mathrm{O}_{43} \mathrm{Na}$, 1835.7727); TLC $\mathrm{R}_{\mathrm{f}} 0.2$ (system b), brown spot by spraying with Komarowsky reagent.

Prosapogenin 3. The spectral data were in full agreement with previously published data for this compound. ${ }^{5}$

Prosapogenin 5. The spectral data were in full agreement with previously published data for this compound. ${ }^{12}$

Determination of Sugar Components. A solution of $\mathbf{1}$ and 2 (7 mg of each) in $\mathrm{H}_{2} \mathrm{O}(2 \mathrm{~mL})$ and $2 \mathrm{~N}_{\text {aqueous }} \mathrm{CF}_{3-}$ $\mathrm{COOH}(5 \mathrm{~mL})$ were refluxed on a water bath for $3 \mathrm{~h}$. After this period, the reaction mixture was diluted with $\mathrm{H}_{2} \mathrm{O}(15 \mathrm{~mL})$ and extracted with $\mathrm{CH}_{2} \mathrm{Cl}_{2}(3 \times 5 \mathrm{~mL})$. The combined $\mathrm{CH}_{2} \mathrm{Cl}_{2}$ extracts were washed with $\mathrm{H}_{2} \mathrm{O}$ and then evaporated to dryness in vacuo. Evaporation of the solvent gave acacic acid lactone $\mathbf{6}(1.5 \mathrm{mg}$ ) (co-TLC with an authentic sample, solvent c). After repeated evaporations to dryness of the aqueous layer with $\mathrm{MeOH}$ until neutral, the sugars were analyzed by Si gel TLC by comparison with standard sugars (solvent system d); for sugars of $\mathbf{1}$ and 2: TLC $R_{f}(g l u c o s e) 0.30, R_{f}$ (rhamnose) 0.50 , $\mathrm{R}_{\mathrm{f}}$ (arabinose) 0.56, $\mathrm{R}_{\mathrm{f}}$ (xylose) 0.45, and $\mathrm{R}_{\mathrm{f}}$ (fucose) 0.49. Furthermore, the residue of sugars was dissolved in anhydrous pyridine $(100 \mu \mathrm{L})$, and L-cysteine methyl ester hydrochloride $(0.06 \mathrm{~mol} / \mathrm{L})$ was added. The mixture was stirred at $60^{\circ} \mathrm{C}$ for $1 \mathrm{~h}$, then $150 \mu \mathrm{L}$ of HMDS-TMCS (hexamethyldisilazanetrimethylchlorosilane, 3:1) was added, and the mixture was stirred at $60{ }^{\circ} \mathrm{C}$ for another $30 \mathrm{~min}$. The precipitate was centrifuged off, and the supernatant was concentrated under a $\mathrm{N}_{2}$ stream. The residue was partitioned between $\mathrm{n}$-hexane and $\mathrm{H}_{2} \mathrm{O}(0.1 \mathrm{~mL}$ each), and the hexane layer $(1 \mu \mathrm{L})$ was analyzed by GC. D-Glucose, D-xylose, D-fucose, L-rhamnose, L-arabinose, and 2-(acetylamino)-2-deoxy- $\beta$-D-glucopyranose for $\mathbf{1}$ were detected in each case ( $\mathbf{1}$ and $\mathbf{2}$ ) by co-injection of the hydrolysate with standard silylated samples, giving single peaks at 18.64, 13.46, 12.14, 13.13, 11.88, and $21.55 \mathrm{~min}$, respectively. In the same manner, identification of D-glucose, D-xylose, D-fucose, L-rhamnose, and L-arabinose was carried out for $\mathbf{2}$, giving single peaks at 18.60, 13.46, 12.12, 13.13, and 11.90 min, respectively.

Alkaline Hydrolysis. Compounds $\mathbf{1}$ and $\mathbf{2}$ (5 mg of each) were refluxed with $5 \%$ aqueous $\mathrm{KOH}(10 \mathrm{~mL}$ ) for $2 \mathrm{~h}$. The reaction mixture was adjusted to $\mathrm{pH} 6$ with dilute $\mathrm{HCl}$ and extracted successively with $\mathrm{Et}_{2} \mathrm{O}(3 \times 10 \mathrm{~mL})$ and $\mathrm{H}_{2} \mathrm{O}$ saturated $\mathrm{n}-\mathrm{BuOH}(3 \times 10 \mathrm{~mL})$. The combined $\mathrm{Et}_{2} \mathrm{O}$ extracts were washed $\left(\mathrm{H}_{2} \mathrm{O}\right)$. Evaporation of the $\mathrm{Et}_{2} \mathrm{O}$ layer yielded salicylic acid 7 (1 mg) (TLC, ${ }^{13} \mathrm{C}$ NMR), identified by comparison with literature data, ${ }^{7}$ whereas evaporation of the $\mathrm{n}-\mathrm{BuOH}$ extract yields the prosapogenin $\mathbf{4}(3 \mathrm{mg})$ (TLC, ${ }^{13} \mathrm{C} N \mathrm{NMR}$ ) from 1, which was identified by comparison of its spectral data with those reported in the literature, ${ }^{5}$ and a prosapogenin $\mathbf{5}(2.5$ $\mathrm{mg}$ ) from 2, previously isolated from the alkaline hydrolysate of the crude saponin mixture of Albizia cortex by comparison of its spectral data with those reported in the literature. ${ }^{12}$ 
Proliferation Assay. The effect of 1-4 on the cell proliferation in J urkat cells was evaluated according to a method previously described in the literature. ${ }^{14}$

Hemolysis Assay. The hemolytic activity of CSM and 1-4 was evaluated on sheep erythrocytes according to a procedure adapted from the literature. ${ }^{15}$

Acknowledgment. We thank Prof. F. Tillequin, University of Paris V, for hel pful discussions.

\section{References and Notes}

(1) Abdel-Kader, M.; Hoch, J .; Berger, J . M.; Evans, R.; Miller, J . S.; Wisse, J . H.; Mamber, S. W.; Dalton, J . M.; Kingston, D. G. I. J . Nat Prod. 2001, 64, 536-539.

(2) Mazzanti, G.; Falconieri Erspamer, G.; Mugné, Y.; Piccinelli, D. Fitoterapia 1983, 65, 275-279.

(3) Zou, K.; Zhao Y.; Tu, G.; Cui, J .; J ia, Z.; Zhang, R. Carbohydr. Res 2000, 324, 182-188.

(4) Zou, K.; Zaho, Y.; Tu, G.; Zheng, J .; Zhang, R. J . Asian Nat. Prod. Res. 1998, 1, 59-66.

(5) Haddad, M.; Khan, I. A.; Lacaille-Dubois, M. A. Pharmazie 2002, 57 705-708.

(6) Rukunga, G. M.; Waterman, P. G. Fitoterapia 2001, 72, 188-190.

(7) Abounassif, M. A. Thian, M. S. Mian, N. A A. In Analytical Profiles of Drug Substances and Excipients; Brittain, H. G., Ed.; Academic Press: New York, 1994; Vol. 23, pp 421-437.

(8) Massiot, G.; Lavaud, C., Besson, V. Bull. Soc. Chim. Fr. 1990, 127, 440-445.

(9) Boughandjioua, N.; Lin, R. C.; Skaltsounis, A. L.; Seguin, E.; Tillequin F.; Koch, M. Can. J . Chem. 1992, 70, 1956-1965.

(10) Hara, S.; Okabe, H.; Mihashi, K. Chem. Pharm. Bull. 1987, 35, 501506.

(11) Lacaille-Dubois, M. A.; Wagner, H. In Studies in Natural Products Chemistry; Atta-ur-Rahman, Ed.; Elsevier: Amsterdam, 2000; Vol. 21, pp 633-687.
(12) Ikeda, T.; Fujiwara, S.; Kinjo, J .; Nohara, T.; I da, Y.; Shoji, J .; Shingu T.; I sobe, R.; Kajimoto, T. Bull. Chem. Soc. J pn. 1995, 68, 34833490.

(13) Lacaille-Dubois, M. A. In Immunomodulatory Agents from Plants; Wagner, H., Ed.; Birkhäuser Verlag: Basel, 1999; pp 243-272.

(14) Gaidi, G.; Miyamoto, T.; Laurens, V.; Lacaille-Dubois, M. A. J . Nat. Prod. 2002, 65, 1568-1572.

(15) Woldemichael, G. M.; Wink, M. Phytochemistry 2002, 60, 323-327.

(16) Haridas, V.; Higuchi, M.; J ayatilake, G. S.; Bailey, D., Mujoo, K.; Blake, M. E., Arntzen, C. J .; Gutterman, J . U. Proc. Natl. Acad. Sci. U.S.A. 2001, 98, 5821-5826.

(17) Yoshikawa, K.; Satou, Y.; Tokunaga, Y.; Tanaka, M.; Arihara, S.; Nigam, S. K. J . Nat. Prod. 1998, 61, 440-445.

(18) Yoshikawa, K.; Suzaki, Y.; Tanaka, M.; Arihara, S.; Nigam, S. K. J . Nat. Prod. 1997, 60, 1269-1274.

(19) Seo, Y.; Hoch, J ; Abdel-Kader, M.; Malone, S.; Derveld, I.; Adams, H.; Werkhoven, M. C. M.; Hisse, J . H.; Mamber, S. W.; Dalton, J . M.; Kingston, D. G. I. J . Nat. Prod. 2002, 65, 170-174.

(20) Debella, A.; Haslinger, E.; Schmid, M. G.; Bucar, F.; Michl, G.; Abebe D.; Kunert, O. Phytochemistry 2000, 53, 885-892.

(21) Ikeda, T.; Fujiwara, S.; Araki, K.; Kinjo, J .; Nohara, T.; Miyoshi, T. J. Nat. Prod. 1997, 60, 102-107.

(22) Kinjo, J .; Araki, K.; Fukui, K.; Higuchi, H.; Ikeda, T.; Nohara, T.; Ida, Y.; Takemoto, N.; Miyakoshi, M.; Shoji, J . Chem. Pharm. Bull. 1992, 40, 3269-3273.

(23) Beutler, J. A.; Kashman, Y.; Pannell, L. K.; Cardellina, J . H., II; Alexander, M. R. A.; Balaschak, M. S.; Prather, T. R.; Schoemaker, R. H.; Boyd, M. R. Bioorg. Med. Chem. 1997, 5, 1509-1517.

(24) Ma, L.; Tu, G.; Chen, S.; Zhang, R.; Lai, L.; Xu, X.; Tang, Y. Carbohydr. Res. 1996, 281, 35-46.

(25) Buckingham, J . B., Ed. Dictionary of Natural Products [CD-ROM], Version 9.1; Chapman and Hall: London, 2000.

NP020391Q 